\title{
Student motivation, identity, and investment construction in French Immersion Studies at the University of Ottawa
}

\author{
Peggy Flynn \\ mflyn051@uottawa.ca \\ UNIVERSITY OF OTTAWA
}

\begin{abstract}
This article focusses on the motivating factors behind the decision of firstyear students in the French Immersion Studies (FIS) program at the University of Ottawa to continue their immersion studies at a university level, how they experience their studies within this program, and how this experience impacts their identity and investment in French language and culture. The findings presented are part of a study that demonstrates the positive influence that parents, teachers, and relevant extracurricular experiences have on students' decision to continue their immersion studies as well as the transformations of the students' identity construction and investment which are enhanced through the FIS program, the bilingual environment which surrounds it, and students' activities
\end{abstract}

Key words: motivation, identity, investment, French Immersion Studies

\section{Résumé}

Cet article porte sur les facteurs qui ont motivé des étudiants de première année à s'inscrire au Régime d'immersion en français (RIF) de l'Université d'Ottawa afin de poursuivre leurs études en immersion au niveau universitaire. Il se penche sur leurs expériences dans ce programme ainsi que sur l'impact de ce programme sur leur identité et leur investissement dans la langue et la culture françaises. Les résultats présentés font partie d'une étude qui montre l'influence positive des parents, des enseignants, et des expériences hors programme sur la décision des étudiants de continuer leurs études en immersion ainsi que sur la transformation de leur construction identitaire et de leur investissement suite à leur participation au RIF, à l'environnement bilingue qui les entoure et à leurs activités.

Mots-clés : motivation, identité, investissement, Régime d'immersion en français 


\section{Introduction}

There is a growing need for research on bilingualism and second language education as Canada's two official languages play an important role in our national identity. Indeed, in present-day Canada, a growing number of Canadians support bilingualism as being advantageous on an economic, cognitive, and social level as well as a way to open doors for employment to improve business and tourism (Rapport du Comité sénatorial permanent des langues officielles, 2015). Additionally, bilingually designated jobs are often higher paying (Mann, Brassell, \& Bevan, 2011). Research also suggests that bilinguals have an easier time learning a third or fourth language (Sanz, 2000). Moreover, researchers such as Bialystok (2011) have underscored bilingualism's ability to prevent cognitive diseases such as Alzheimer's, and to lessen the effects of aging and improve creativity, concentration, mental agility and reasoning skills. On a socio-cultural level, benefits associated to bilingualism include its ability to contribute to national unity, its potential benefits to interpersonal relationships, and its power to foster improved communication between different communities including the ability to work around the world for travel and studies (Rapport du Comité sénatorial permanant des langues officielles, 2015). Bilingualism can also contribute to greater self esteem and new identities. As Fortune (2014) puts it, "Becoming bilingual leads to new ways of conceptualizing yourself and others. It expands your worldview, so that you not only know more, you know differently" (p. 4; italics in original). Recent statistics suggest that many Canadians are aware of the benefits associated with bilingualism as they seek to develop greater expertise in another language.

The goal of this study is to examine how students who decide to continue studying French at a university level (more specifically first-year students in the French Immersion Studies Program at the University of Ottawa) experience their studies within this program as well as the factors that influence their decision to continue studying in immersion at the university level. Topics of interest include an investigation of the factors which influence their decision to pursue immersion studies at the University of Ottawa, the obstacles and challenges they experience in their first year, and the consequences of these experiences on how the students see themselves and the goal of learning French.

In order to explore these topics, the study draws on two theoretical frameworks. Firstly, it draws on work which explores identity and investment in sociocultural theory: more precisely, Norton's poststructuralist's construct of investment. Secondly, it draws on concepts which stem from psychological theories of motivation, including Gardner's socio-educational model of motivation and second language acquisition (SLA). The research questions that guide this study are the following: 
- What are the factors that influence undergraduate first-year students to pursue their immersion studies at a university level?

- What are the experiences and perceptions of first-year students studying in the French Immersion Studies (FIS) program at the University of Ottawa?

- How does the students' experience in the FIS program impact their identity and investment in French language and culture?

The University of Ottawa is the largest bilingual university in North America and has the largest tertiary immersion program in Canada. The FIS program at the University of Ottawa has been in existence since 2006. In 2015-2016, 600 students from across the nation came to study in French in 87 different undergraduate programs to maintain or improve their second language proficiency. The University of Ottawa pamphlet for the FIS program states that compared to the general student population at the University of Ottawa, more of their French Immersion students have better admission averages, university grades, survey satisfaction rates and graduation rates. This hints at the fact that it is likely that we see very strong students entering these programs from all over Canada and thus the importance of the support structures for these programs should not be taken lightly. It is also likely these are students who are proud of their achievements and their decision to continue studying in their second language. This study will provide an opportunity to explore how the University of Ottawa's sense of their students is actually supported by empirical research with a focus on investigating the realities of these students' experiences within a university-based immersion program.

Students at the University of Ottawa who choose to register in the FIS program study in French content courses in their chosen fields alongside native speakers have the option to enroll in an adjunct language course designed to complement the content course (Séror \& Weinberg, 2013). They must complete a minimum of 14 courses taught in French over the course of their fouryear program to develop skills relevant to their field of study and receive the French Immersion designation on their diploma. The immersion program offers a supportive environment which helps students mitigate the risk of completing part of their undergraduate degree program in French at the university level. For instance, in their first two years of study, students can opt to receive a qualitative grade (pass/fail) rather than a numeric grade for up to eight of their courses taught in French. These qualitative grades do not contribute to the calculation of students' GPA (grade point average), thereby alleviating some of the anxiety surrounding completing content courses in their program in their second language. Indeed, there is a concern among some students that studying in French will cause them to receive lower marks because of the increased 
difficulties associated to working with disciplinary knowledge in a second language when they take courses taught in French. The students can also take advantage of several established support systems such as scholarships, individualized programs, a student mentoring program, conversation workshops, the use of the Academic Writing Help Centre, and an immersion club. All these forms of support give students the ability to take the risk that is involved in completing their undergraduate degree with the immersion option (Séror \& Weinberg, 2013).

This encouragement and support also fulfill another important function which is to ease students' transition from high school to university immersion. This transition has sometimes been identified in the research as one that is fraught with difficulties for students as they traverse the social and academic gap from high school to university (Lamoureux, 2013).

To explore in greater detail the transition and the answer to the questions posed above, this study looked at an in-depth examination of four case studies. In doing so, the goal was to better understand why the focal students have chosen to continue their immersion studies (and why at the University of Ottawa) as well as their perceptions, experiences, challenges, motivation, identity, and investment in the FIS program during their first year of studies. Case studies are ideal for this type of research as they are particularly efficient in gathering rich detailed accounts of the cases (Duff, 2014).

Ultimately, the outcomes of this study should allow us to better understand the students' experiences of transition to and their first year of study in the immersion program at the University of Ottawa. Additionally, we will gain a better insight into the influences and factors that contributed to their decision to follow this route. This information will provide enhanced insight about the students' experiences in university immersion programs, which will in turn help us better understand how these programs are experienced and lived by the students participating.

\section{Methodology}

A multiple case study design (Duff, 2014; Pearson Casanave, 2010) was used drawing on both quantitative and qualitative data sources with the goal of enhancing our understanding of students' experiences in the FIS program. This study draws from a larger data set which was collected as part of a longer longitudinal study held at the University of Ottawa. Drawing on the multiple sources a rich and in-depth portrayal of the participants' perception of the program, their experiences during their first year of study in their new surroundings and their changing and evolving identities and investment in the program was produced. The cases for this study were drawn from a body of students who were recruited in the fall of 2015 for the ongoing four-year longitudinal 
study by Professors Séror and Weinberg. The students were volunteers who accepted an invitation sent out to the cohort of all first-year students in the fall of 2015. The purpose of this study is to produce a long-term account of the trajectory of the immersion students as they participate in the FIS program with a focus on the development of their identities as bilingual and their abilities as L2 learners over the course of their four-year program. Forty-six students ultimately accepted the invitation to participate in the study and gave their consent to participate, with the understanding that they would always have the option to leave the study at any time. To select the four participants who are at the heart of this research paper, the following steps were taken. Data stemming from the original cohort of 46 recruited students was examined to identify a limited number of focal participants, who then became the focal cases whose data were used to answer the three research questions which have been posed for this particular research project. Ultimately four cases were chosen for a multiple case study after reading all of the questionnaires and listening to all of the interviews. Although it was difficult to choose amongst the forty-six students in the study, these particular participants were chosen because they had such interesting perspectives, were extremely articulate, and provided rich descriptions of their experiences both semesters.

Although the students in the four-year longitudinal study came from all three streams of French language learning programs found in Canadian public schools (French Immersion programs, Extended French programs and Core French programs), all four focal participants selected for this project were from early immersion programs and had attended Ontario high schools. This is in contrast to the full cohort of participants in the larger longitudinal study which contained $85 \%$ of applicants coming from Ontario, 5\% from Québec, 5\% from British Columbia and 5\% from other Canadian provinces. As well, all four focal participants were female students. This compares to the approximately $80 \%$ of students presently registered in the FIS program who are female (Rapport d'auto-évaluation du RIF, 2014).

The initial data collection step for all participants in the longitudinal study was the distribution of a questionnaire to gather information about their attitudes regarding their language abilities as well as demographic information about the students. Additionally, one focus group and two individual semiformal interviews took place to collect further data from the students. The focus groups took place in October 2015, the first semi-formal interview took place between December 2015 and January 2016 depending on students' availabilities. In the spring of 2016, a second semi-formal interview took place after the completion of the students' first year of studies. The purpose of the interviews was to gather information on French immersion at the University of Ottawa both from the perspective of objective measurements as well as from the 
students' perceptions. The interviews lasted on average 30 minutes and were conducted by Professors Weinberg and Séror one-on-one and face-to-face. The students were given the option to respond in English or in French. Although many chose French, some students actually chose to do their interviews in both languages, ultimately code switching and answering some questions in French while switching to English to answer other types of questions, based on their personal choice.

Quantitative data stemming from the demographic questionnaires were analyzed in coordination with the qualitative data to link the quantitative attributes found in the questionnaires to some of the themes which emerged from the qualitative data. The information from the questionnaires allowed us to scan profiles and better understand the qualitative data through the triangulation of ideas presented in the interviews with case-specific details contained in the questionnaires.

\section{Findings}

The purpose of this study is to analyze the richness of the students' insights during their interviews at the end of their first and second semesters in their first year of studies. The answer to the questions posed were organized into four themes which emerged from the findings as a result of the analyses which were conducted. This was done by examining the case studies and looking at recurring themes that emerged from the semi-formal interviews that were relevant to this study and to the participants' experiences regarding their identity and investment in their learning of French in the FIS program.

In order to protect the students' anonymity, participants were given pseudonyms: Cora, Nadia, Lara, and Sophia. Although all four cases are female, were scholarship winners, and came from within the province of Ontario, these focal participants were representative of the larger population of participants in the French Immersion Studies program, based on the Rapport d'auto-évaluation du RIF (2014) which found that $80 \%$ of participants in the FIS program were female, $85 \%$ came from Ontario, and that the majority of the students were scholarship recipients. The perception of the participants' experiences to date as well as their evolving identities and further investment in their immersion education will be explored in further detail as each key research question is examined in light of the data collected with findings substantiated with quotations taken from their interviews, and discussed in detail in the four themes below.

\section{Theme 1: What were the reasons which motivated the students to pursue a post-secondary immersion program?}

In addition to the financial incentives offered by the University of Ottawa, key findings emerged suggesting that the following reasons were also important 
to the students' decision to enter the FIS program: the influence of teachers and parents, the immersion program in a bilingual environment, and prior relevant experiences such as exchanges and trips to French-speaking cities and countries. All of these were catalysts for further investment in the participants' bilingual education.

In the case of Sophia, her love of the language and culture was cemented in an exchange in France in grade 8 . She recounts in her fall interview: ${ }^{1}$

Sophia J'ai fait un échange en France pour deux mois et là j'étais exposée à la culture française de France et j'adorais complètement ... C'est pourquoi je voulais venir à Ottawa, parce que je voulais améliorer mon français, mais aussi comme apprendre un peu plus de la culture...

[I did an exchange in France for two months and was exposed to French culture there and I completely adored it ... That's why I wanted to come to Ottawa, because I wanted to improve my French but also like, learn more about the culture ...]

When Nadia was asked who or what influenced her to continue in French, she emphatically described her high school French teacher who loved French and who engaged the students in their learning through well-organized activities and projects.

Nadia Elle adorait le français et depuis la 9e année elle nous avait poussés à continuer nos études et vraiment, même les étudiants qui n'aimaient pas le français, ils s'amusaient dans la classe de cette professeure parce que, comme, ce n'était pas une classe facile de tout, mais les activités ont vraiment été bien organisées pour que nous pouvons meilleur comprendre. Elle vraiment savait comment enseigner le cours. Cela m'a vraiment poussée, et aussi cela m'a poussée d'adorer le français et ça c'est pourquoi je voulais comme continuer mes études. (fall interview, emphasis in the audio)

[She loved French and from grade 9 on she pushed us to continue our studies and really, even the students who didn't like French, they had fun in that teacher's class because, like, it wasn't an easy class at all but the activities were really well organised so that we would understand better, she really knew how to teach that course. That really pushed me, and it also pushed me to love French and that is why I wanted to, like, continue my studies.]

Lara talked explicitly about being influenced by and grateful to her Portuguese father for instilling a love of language in her. Her father was essential in making her realize that languages could "open so many more doors" and he also constantly pushed her to always do better. In addition to this realization, Lara also talked about the cognitive advantages and the heightened awareness bilingualism could create. She found that being in French immersion in high school was a source of pride and confidence and that the students in the im-

\footnotetext{
${ }^{1}$ Quoted material has not been edited or corrected.
} 
mersion stream were "more inclined to do stuff" and had "that extra kind of strive". She felt she "had a deeper understanding of some things" and that "it helped us organize our time better". When discussing the impact of immersion, she also talked about how immersion had made her more "open-minded" and helped her to avoid pre-judgement. Lara felt she has become a better person because of her bilingualism and of her decision to continue to enjoy the two languages and cultures. These are all advantages she recognized and were part of the reasons she loved French and the diversity of bilingualism. She was not willing to lose these advantages and like Nadia, this desire to preserve advantages which she associated to her previous experiences as a French language learner were key to her decision to choose to continue in the FIS program.

\section{Theme 2: What were the students' perception of the FIS program and the University of Ottawa?}

The interviews revealed interesting elements about what students felt about the services offered by the University of Ottawa. For instance, Nadia was so enthusiastic about her experiences in the FIS immersion program that she stated that she had posted very positive update statuses on social media of her experiences within the program.

Cora discussed how much she liked the adjunct language course she took in conjunction with her History course taught in French. She stated that the reason she would "definitely" stay in the immersion program was that she wanted to improve her French by taking more content courses and by living in an apartment with Francophones with a French-only house rule.

Sophia was another student who was very happy with her decision to enter the FIS program as she self-identified as being passionate about French language and culture and wanted only to improve.

Sophia J'adore cette programme là et j'adore avoir, comme, l'opportunité de le faire en français. Donc, c'est juste ... le français c'est un de mes passion et je veux, comme, participer encore plus en cette programme et être, euh ... un peu comme un défi pour moi même pour être-avoir, comme, plus de compétences en français ... Et puis de plus en plus je suis tellement contente que j'ai choisi de faire le programme français immersion. (spring interview)

[I love this program and I adore having, like, the opportunity to do it in French. Therefore, it's just ... French is one of my passions and I want, like, to participate even more in this program and be, um, a bit like a challenge for myself to be have like, more skills in French ... And I'm increasingly happy that I chose to do the French immersion program.] 


\section{Theme 3: The impact of the students' experiences on their identity and investment in French language and culture}

One interesting finding with regards to investment is seen in the case of Lara. When talking about a return trip home, she noted that it was at this point that she became conscious that an important element in her new life as a university student was lacking in her home town:

Lara When I go back to Toronto speaking French is a novelty. Here (in Ottawa) it is kind of well, yeah, if you don't speak French it is weird. But I don't know, like when I went back to Toronto last time, I was on the subway and nobody was speaking French and it was like, it's kind of boring!

Later on, Lara used the word pride to describe her changing bilingual identity. Sophia discussed the cognitive and social changes she experienced. As a result of coming to the University of Ottawa, she stated that she saw herself transforming and identifying more with French language and culture:

Sophia J'en ai l'envie de parler en français puisque mon cerveau c'est comme transféré en français plutôt qu'anglais ... C'est plutôt comme ce sens de francophonie je trouve que j'en ai plus ... (fall interview)

[I feel like speaking French because my brain has like transferred to French rather than English ... It's rather, like, this meaning of Francophonie that I find I have more of ... ]

Nadia highlighted in her interviews how the experience had allowed her to discover a different, less Americanised Canadian culture and ultimately to build up her sense of what being a Canadian meant. In a further example of these findings, Nadia revealed in her interviews her strengthening connection with the French target language community and her passion for the rights of Francophones, elements which help to reinforce her feelings surrounding the importance of bilingualism.

\section{Theme 4: The students' future plans for further investment in French lan- guage and culture}

When the focal participants were asked about the future and whether they anticipated participating in any activities which involved using their French, all four students revealed that they had made plans which included further investment in French language and culture.

Cora, for example, discussed sharing an apartment with a Francophone friend and a bilingual friend and her decision to speak only in French with her roommates. Nadia talked about going to France in the summer to be a bilingual tour guide at a sightseeing site in France. Lara shared that she would be taking 
part in the Explore Summer Language Bursary Program ${ }^{2}$ in Nova Scotia in the summer. Sophia projected to stay and work in Ottawa in the summer, a sign of her feelings that she had a growing sense of connection with her new adopted city and what it could offer her as a chance to grow and live her life here versus her hometown.

As for longer-term projects, Sophia and Lara both plan to take part in an international exchange in France set up by the University of Ottawa in their third year of studies. Cora plans on taking more content courses in French, and Nadia will become a CA (community advisor) in her residence, a bilingual position she is looking forward to.

\section{Discussion}

The data collected for this study revealed that the FIS program did indeed impact the identity and investment of the four focal students in several ways; these included a transformation and identification with French language and culture, a (re)discovery of Canadian culture, a growing sense of alliance with the Francophone community, a passion for more balanced rights and services for both of Canada's official languages, and a growing appreciation of the value of bilingualism. In terms of Norton's (2013) theory of identity and investment, this data strongly suggests that these focal students' academic and social investment in the target language community entailed by their participation in the FIS program at the University of Ottawa contributed to their evolving sense of self as bilingual both now and in the future as they made decisions and expressed their sense of where future commitments and investment in the target language community would lie.

The implementation of the goals of the 2013 Framework for French as a Second Language in Ontario's Schools (as well as the federal objective to promote linguistic duality) can be looked at more closely in regard to the findings. For instance, Goal 1 "Increase student confidence, proficiency, and achievement in FSL [French as a Second Language]" can be achieved when all stakeholders realize the importance of having students apply their language skills inside and out of the classroom and in authentic situations, as confidence, proficiency and achievement are all interrelated. Goal 2, "Increase the percentage of students studying FSL until graduation" adds "and beyond" in its description of the goal of students' lifelong language journey. Therefore, post secondary immersion programs should be actively promoted in Canadian high schools. And finally, Goal 3 "Increase student, educator, parent, and community engagement in FSL" calls on all stakeholders to realize the importance of increasing the awareness of the benefits of SLA.

\footnotetext{
2 www.myexplore.ca/en.
} 
In addition to contributing to the theoretical understanding of the impact of university level immersion programs, the study's findings offer insights which can help immersion teachers better understand aspects of student motivation. For instance, the findings of this study illustrated how extracurricular activities such as exchange programs can have a life-changing effect on students' identity and investment in their language learning as seen in the case of Sophia's exchange in France. Additionally, the findings strengthened arguments in favour of how teachers can have a profound impact on students' investment and decision to continue their immersion studies at a university level, as Nadia's enthusiastic teacher had on hers. Similarly, this work may help strengthen teachers' awareness of the impact they can have when they promote post-secondary immersion programs in their classrooms and highlight different choices available to students who are making decisions about their post-secondary careers. Although College and University Days (days when college and university representatives set up booths explaining their various programs and incentives) take place in most high schools across the country, they have been known to overwhelm students with too much information from too many sources. A potential solution to this issue might be for teachers to take the initiative to invite representatives from institutions which offer immersion options (including potentially students who are presently registered in these programs) into their classroom to offer presentations. Such talks would increase high school immersion students' chances to take part in a multi-media presentation, ask pertinent questions and access informed answers about the immersion programs available after high school graduation. Several institutions offer to send liaison officers to speak to FSL classes and although there are many time restraints on teachers, this could be a very good use of class time.

Hopefully this research will contribute to helping teachers, administrators and Department of Education consultants by providing them with useful information to encourage students to continue their immersion studies by actively promoting post-secondary immersion programs. In doing so, some students may realize the benefits of such programs, reap the numerous rewards of living in the target language community, continue to raise their competence while avoiding losing the skills they have worked hard to obtain for the past 12 years, and potentially become our future immersion teachers themselves to fill positions that are crying for qualified French teachers.

\section{References}

Bialystok, E. (2011). Reshaping the mind: The benefits of bilingualism. Canadian Journal of Experimental Psychology, 65 229-235.

Canada, Parliament, Senate. Comité sénatorial permanant des langues officielles. (2015). Viser plus haut: Augmenter le bilinguisme de nos jeunes Canadiens. $41^{\mathrm{e}}$ 
législature, $2^{\mathrm{e}}$ session, Rapport 6 . Retrieved from the Parliament of Canada website: sencanada.ca/Content/SEN/Committee/412/ollo/rep/rep06jun15-f.htm.

Duff, P. (2014). Case study research on language learning and use. Annual Review of Applied Linguistics, 34, 233-255.

Fortune, T.W. (2014). What the research says about immersion. Center for Advanced Research on Language Acquisition (CARLA), University of Minnesota. Available at: carla.umn.edu/immersion/documents/ImmersionResearch_TaraFortune.html. [Originally published 2012 in Chinese Language Learning in the Early Grades: A Handbook of Resources and Best Practices for Mandarin Immersion (pp.9-13).]

Lamoureux, S. (2013) L'expérience étudiante au Régime d'immersion en français : perspectives et constats. Cahiers de l'ILOB, 6, 109-121.

Mann, A., Brassell, M., \& Bevan, D. (2011). The economic case for language learning and the role of employer engagement. Retrieved from the Education and Employers Taskforce website: www.ucml.ac.uk/sites/default/files/shapingthefuture/ 101/Language\%20learning\%20research\%20report.pdf.

Norton, B. (2013). Identity and language learning: Extending the conversation (2nd ed.). Bristol, UK: Multilingual Matters.

Ontario. Ministry of Education. (2013). A framework for French as a second language in Ontario schools: Kindergarten to Grade 12. Toronto. Available at: www.edu.gov. on.ca/eng/amenagement/frameworkFLS.pdf.

Pearson Casanave, C. (2010). Continuum companion to research methods in applied linguistics. New York: Continuum International Publishing Group.

Sanz, C., (2000). Bilingual education enhances third language acquisition: Evidence from Catalonia. Applied Psycholinguistics, 21, 23-44.

Séror, J., \& Weinberg, A. (2013). Personal insights on a postsecondary immersion experience: Learning to step out of the comfort zone. Cahiers de l'ILOB, 6, 123-140.

University of Ottawa. (2014). Rapport d'auto-évaluation du programme. Internal document, French Immersion Studies [Régime d'immersion en français]. University of Ottawa. 